PERM JOURNAL OF PETROLEUM AND MINING ENGINEERING

ВЕСТНИК ПНИПУ. ГЕОЛОГИЯ. НЕФТЕГАЗОВОЕ И ГОРНОЕ ДЕ

ISSN 2224-9923

Volume / Tом 17 №2 2018

http://vestnik:pstu.ru/geo/

УДК 622.276.72

Article / Статья

(c) PNRPU / ПНИПУ, 2018

\title{
CLEANING THE WELL FROM WAX DEPOSITION BY HIGH-FREQUENCY AND ULTRA HIGH-FREQUENCY ELECTROMAGNETIC EXPOSURE
}

\section{Lenart M. Fatykhov}

PermNIPIneft branch of LUKOIL-Engineering LLC in Perm

(29 Sovetskoy Armii st., Perm, 614066, Russian Federation)

\section{ТЕХНОЛОГИЯ ОЧИСТКИ СКВАЖИН ОТ АСФАЛЬТЕНОСМОЛОПАРАФИНОВЫХ ОТЛОЖЕНИЙ ПУТЕМ ВОЗДЕЙСТВИЯ ВЫСОКОЧАСТОТНОГО И СВЕРХВЫСОКОЧАСТОТНОГО ЭЛЕКТРОМАГНИТНОГО ИЗЛУЧЕНИЯ}

\section{Л.М. Фатыхов}

Филиал ООО «ЛУКОЙЛ-Инжиниринг “ПермНИПИнефть”» в г. Перми

(614066, Россия, г. Пермь, ул. Советской Армии, 29)

Received / Получена: 28.05.2018. Accepted / Принята: 09.06.2018. Published / Опубликована: 29.06.2018

Key words:

wax deposits, oil pipeline, well, high-frequency and ultrahighfrequency method, temperature, dielectric loss, frequency.

\section{Ключевые слова:}

отложения асфальтеносмолопарафиновых веществ, нефтепровод, скважина, высокочастотный и сверхвысокочастотный метод, температура, диэлектрические потери, частота.

\begin{abstract}
According to information over the world, production of high content paraffin oil is followed by a serious problem causing challenges in operation of wells. The problem is wax deposition on the inner surface of oil field equipment. The problem decreases system production and efficiency of operation of pumps, the failure of wells, control devices and oil collection and transportation systems. Wax deposition can lead to a complete closure of lifting pipes and annular channels in the interconnecting space, which causes the necessity of workovers to eliminate the wax deposition.

This article describes the geophysical bases of the influence of high-frequency and ultra high-frequency electromagnetic fields for the heating and removal of wax from wells. Results of experimental studies of dielectric losses in wax samples of some oil fields are presented. Their dependence on frequency and temperature, as well as on the content of resins and asphaltenes in samples is established. The possibility of experimental determination of the melting point of wax by the data of dielectric studies is shown.

Calculation studies of heating and melting the wax plugs in the oil pipeline were carried out under the influence of the type of electromagnetic waves capable of propagating in it as in a round waveguide. It is believed that the source of electromagnetic waves is moving. That allows overheating of the medium at some points and melts solid deposits along the entire length of a plug. Results of numerical studies allow monitoring the dynamics of heating and elimination of a wax plug by electromagnetic action.
\end{abstract}

Lenart M. Fatykhov - Head of Team for Design and Monitoring of Development of Pechora Group of Fields (tel.: +007 987 250 60 92, e-mail: lenfort@inbox.ru).

Фатыхов Ленарт Миннеханович - руководитель группы проектирования и мониторинга разработки Печорской группы месторождений (тел.: +007 9872506092 , e-mail: lenfort@inbox.ru). 


\section{Introduction}

Oil and gas fields are depleted with time causing production of unconventional oil, located in complex geological and technical conditions of development, and decrease in quality of reserves. As a consequence, general balance of the fields, being developed today, mostly contains fields at the late production stage. There is a tendency to increase the share of unconventional oil reserves [1]. Those fields include deposits of oil characterized by high viscosity and content of asphaltene, resin and paraffin matter (ARPM).

Natural thermobaric conditions of the deposits change during oil recovery. That leads to deposition of ARPM on the walls of wells and production tubing, in pumping equipment and ground communications [2]. In order to prevent deposition chemical reagents (inhibitors, demulsifiers etc.), magnetic and acoustic fields are used for treatment. Thermal methods for removing ARPM, in particular, by pumping hot oil or solvent reactants, which interact with exothermic reactions are widely used $[3,4]$.

Development of technologies and techniques to combat the formation of ARPM has a long history [5]. However, it can not be said that today all the difficulties connected with the solution of this problem have been overcome. A variety of conditions for development of deposits and characteristics of extracted oil requires individual approaches [3, 6-9].

Based on the model of formation of paraffins or crystal hydrates when thermobaric conditions change and mechanical adherence of deposits to the walls of the wells, ARPM and crystal hydrates are removed by pumping into the well various reagents that dissolve the deposits (or warm up their zone), either by well heaters or mechanical means using scrapers. Some technologies allow removing deposits even if there is no circulation inside the tubing [3].

In particular, in order to prevent the formation of crystalline hydrates methanol is added to the gas flow.

There is a number of special methods along with general ones. For example, in order to prevent the formation of crystal hydrate plugs dehydration of the pumped gas is used, method of pressure drawdown at ends of a pipeline, use of laser radiation to excite molecular levels etc. Despite the differences all these methods are expensive, difficult to implement or require the company for production of chemicals, very often toxic, such as methanol.

Those forces are search for new cheaper and safer methods of preventing the formation and destruction of crystal hydrate and paraffin plugs. The results of studies conducted both in our country and abroad testify to the fact that one of the effective methods of combating ARPM, which is fundamentally different from traditional ones, is use of energy of high frequency (HF) and super high-frequency (SHF) (microwave) electromagnetic fields (EMF) [10-19]. Heating has the most significant effect that occurs as a result of transition of energy of electromagnetic radiation into the internal energy of the medium during its polarization.

The technology of combating ARPM deposits in oil-producing wells with help of energy of HF and SHF of EMF differs because the well serves not only as a pipe through which oil is extracted to the surface, but also as a waveguide or a coaxial line through which the energy of EMF is transported. Efficiency of this process depends on electromagnetic power in the well.

\section{Physical basis, technical and technological features of high-frequency electromagnetic fields impact on asphaltene, resin and paraffin matter deposits in the well}

In terms of HF electrodynamics, wellbores and pipelines represent transmission lines (coaxial lines, cylindrical waveguides) for electromagnetic waves. Phase and group velocities of electromagnetic waves, their damping are determined by the type of waves, material of pipeline walls and dielectric properties of hydrocarbons. A HF emission directed from an external generator to the plug can heat the plug to the melting point of the paraffin or decomposition of the crystalline hydrate and, thus, to remove the obstacle [4-12]. A volume character is an essential advantage of the HF method of heating the plugs, since electromagnetic waves in the HF range can penetrate into the plug material to a great depth. In addition, by changing the power level of the HF generator and frequency of electromagnetic radiation, it is possible to control the heating process, since the dielectric constant and tangent of 
dielectric loss angle of the plug material depend on radiation frequency and temperature.

The physical basis of the method consists of release of heat in the medium filling the shell space and in walls of the well pipes when electromagnetic waves propagate along it from the ground generator. The system of tubing and casing strings is an electrical a coaxial transmission line with imperfectly conducting walls and the annular space is filled with a dielectric that absorbs the energy of the electromagnetic field good enough. As a result, some of the electromagnetic energy passes into the thermal energy, solid deposits are heated and melted in the entire volume simultaneously.

The ARPM deposits are dielectrics characterized by a complex relative permittivity:

$$
\begin{gathered}
\dot{\varepsilon}_{d}(\omega, T, p)=\varepsilon_{d}^{\prime}(\omega, T, p)-j \varepsilon_{d}^{\prime \prime}(\omega, T, p), \\
j=\sqrt{-1},
\end{gathered}
$$

where $\varepsilon_{d}^{\prime}, \varepsilon_{d}^{\prime \prime}-$ real and imaginary parts of the dielectric constant of a medium; $\omega$ - cyclic frequency, $\omega=2 \pi f ; f$ - linear frequency of an electromagnetic wave; $T$ and $p$-temperature and pressure.

The imaginary part of the dielectric constant determines density of heat sources that arise in the material when it interacts with a high-frequency electromagnetic field (HF EMF)

$$
\dot{E}=\dot{E}_{0} \exp (j \omega t), \quad \dot{H}=\dot{H}_{0} \exp (j \omega t) \text {. }
$$

The density of heat sources is described by the formula:

$$
q=0,5 \omega \varepsilon_{d}^{\prime} \varepsilon_{0} \operatorname{tg} \delta \dot{E}_{0} \dot{E}_{0}^{*}, \operatorname{tg} \delta \approx \frac{\varepsilon_{d}^{\prime \prime}}{\varepsilon_{d}^{\prime}} .
$$

The spatial-temporal temperature change in the ARPM deposits filling the well is found from the solution of the heat-conductivity equation:

$$
c \rho \frac{\partial T}{\partial t}=\lambda \Delta T+q
$$

In the formulas (2)-(4) $\varepsilon_{0}$ - dielectric constant of vacuum; $\dot{E}, \dot{H}$ - intensity of the electric and magnetic fields, respectively; $\dot{E}_{0}, \dot{H}_{0}-$ their amplitudes, depending on the spatial coordinates and time; c, $\rho, \lambda$ - specific heat, density and coefficient of thermal conductivity of the medium, respectively. Thus, when ARPM interact with HF EMF internal heat sources emerge in ARPM and, as a consequence, its temperature and pressure change allowing using energy of powerful electromagnetic radiation for elimination of ARPM, formed in various nodes of equipment.

Allocation of additional heat in the material of equipment nodes due to finite conductivity is one of the advantages of this method as well.

A number of authors have studied the effect of HF and SHF EMF on ARPM or on its components. Thus, processes of heating and melting of paraffin plugs in oil wells and oil pipelines by powerful electromagnetic radiation in a mode of continuous generation of electromagnetic waves are studied in the paper [15]. In order to select the power and frequencies of the HF source the time needed for through channel to be formed in a plug and time of its complete elimination are determined taking into account the heterogeneity of the HF power distribution along the borehole section and ohmic absorption of HF power in metal walls of the well pipes. Since the metal walls are in thermal contact with a paraffin plug, an additional warming up factor of the paraffin plug appears. In a number of cases, in particular in case of equipping oil wellbore, if heating of a plug by steel walls is taken into account, then it significantly reduces time of melting of a paraffin plug. The melting process proceeds gradually from a central region of wellbore to periphery so that the molten paraffin zone has a conical shape. The conical shape of the molten zone can lead to the destruction of the plug until it is completely melted. Numerical examples considered in [13-15] in the coaxial borehole of oil well equipment, a paraffin plug $100 \mathrm{~m}$ long is completely eliminated for 34 hours at $\mathrm{HF}$ generator power of $10 \mathrm{~kW}$ and working frequency of $10 \mathrm{MHz}$. When the power is increased to $20 \mathrm{~kW}$, the time for eliminating the plug is reduced to 12 hours.

The analysis of the process of elimination of paraffin plugs in borehole of an oil well by HF source operating in the regime of periodic switching on and off (periodic operation) was also carried out. It is shown that in this mode the total time for eliminating the plug essentially depends on the power of HF source and duty cycle of its operation. At a fixed power of the HF source total time of melting of a plug increases nonlinearly with increasing duty cycle. The total (summary) operating time of the RF source itself with 
increasing duty cycle of the RF generator increases as well. These patterns are explained by increase in thermal losses with increasing duty cycle (time of switching off the HF source). It is determined, that the total operating time of the source (or the energy expended at a fixed power) depends little on its operating time within a single cycle. There is a threshold value of porosity, in which the complete penetration of the paraffin plug is never achieved.

In terms of electrodynamics a well is a coaxial transmission line. Due to peculiarity of the wave dispersion in the coaxial line, the optimal value of the operating frequency can always be chosen, which corresponds to the value of HF power absorption coefficient in the plug equal to the reverse length of the plug. The oil pipeline can be considered as a cylindrical waveguide capable of transmitting electromagnetic waves with a frequency higher than the cutoff frequency. At the frequencies mentioned there is a strong absorption of HF power and heating only a narrow region of the plug adjacent to a HF generator. In order to eliminate paraffin plugs in these conditions it is proposed to use a moving source of electromagnetic radiation. The speed of its movement is controlled by velocity of the interface between the liquid and solid phases during the melting of a paraffin plug under influence of highfrequency electromagnetic radiation. The speed of a HF-power source and time of complete elimination of the plug are determined. It is shown that for selected parameters of a moving HF source and paraffin plug the part of energy consumed for melting the paraffin plug reaches $70 \%$.

The HF cleaning of the oil pipeline from paraffin deposits at early stage of their formation, when the deposits do not yet clog the oil pipeline, is studied. Cleaning is carried out by a moving HF source. It is shown that the time of high-frequency cleaning essentially depends on the magnitude and position of the maximum power density of heat release. If the frequency is increased then the maximum power density of heat release shifts from the center to the wall of pipeline, where the paraffin layer is localized. The maximum value of power density of heat release is increased as well. Accordingly, the cleaning time is reduced. The time dependence of oil pipeline cleaning on the thickness of paraffin deposits is significant only for small HF power levels. Initial temperature of oil has little effect on HF cleaning time.
Earlier, the processes of heating and melting paraffin plugs in the oil well were considered in [15]. In this case, the model of a homogeneous distribution of the HF field over the cross section of a wellbore is used. In addition, the ohmic absorption of HF power in walls of the wells was not taken into account, which would lead to an additional damping of electromagnetic radiation during its propagation and, accordingly, to heating of walls. In fact, distribution of HF power in a well cross section for the electromagnetic cable waves considered (TEM type), is highly nonuniform. Taking into account the inhomogeneous radial distribution of HF power leads to qualitative and quantitative features of heating and melting of the plug in a wellbore. Besides, additional damping of TEM waves in the borehole caused by losses of HF power in walls of the wellbore was taken into account. Dissipation of HF power in steel walls of pipes leads to their heating. Since steel walls are in thermal contact with a paraffin plug, an additional channel for heating the plug is formed.

There was a laboratory installation developed and studies of heating and melting of paraffin under the effect of electromagnetic oscillations in a short-circuited coaxial system performed in [16]. It is shown that, depending on filling of intertube space with paraffin or air, melting of paraffin can occur both as a result of its heating by thermal conductivity and because of distributed heat sources in the system under the influence of the electromagnetic field. The rate of heating and melting of paraffin in a coaxial system is much greater in the second case than in the first one. These rules are significantly influenced by dielectric properties of paraffin and electromagnetic properties of pipe materials. With all other conditions being equal, heating and melting of paraffin occurs in the field of a standing electromagnetic wave formed due to its reflection from inhomogeneities of tube surfaces of and coaxial line.

Thus, the results obtained in these studies confirm the promise of the electromagnetic well treatment method with the aim of removing deposits and increasing their throughput.

Tansformation of electromagnetic energy into thermal one occurs most intensivy in the range of high-frequency waves. The question is how to transfer the electro-magnetic energy into the medium intended for this purpose. Not every 
transmission line can transmit electromagnetic waves of any frequency. For example, electromagnetic energy is transmitted on a coaxial transmission line by TEM waves which do not have restrictions on the frequency. Waveguides have critical frequencies below which electromagnetic waves can not be transmitted [20].

A coaxial transmission line is a well in which tubing and casing can represent an internal and external wire if they do not touch each other. If they touch each other then electromagnetic energy can be transmitted along the inner surface of tubing. If such is the case, then in terms of electrical dynamics tubing represents a circular waveguide. Oil and gas pipelines are also a circular waveguides.

In a circular waveguide waves of the type $E$ or $\mathrm{H}$ can be transmitted only [20]. If an oil pipeline has a small radius, then electromagnetic waves with very high frequency can propagate in it only, which subside quickly due to adsorbtion of a medium. Therefore, the environment is heated extremely unevenly. So, at some points there may be severe overheating and large losses of heat to the surrounding oil pipeline environment. At other points, on the contrary, the heating is not sufficient for melting the medium. As a consequence, a plug can only be destructed for a shallow depth. Under these conditions ARPM can by destroyed with help of a moving source of high-frequency electromagnetic waves - "EM Krot". In this method, the source of high-frequency electromagnetic radiation moves as a medium melts and movement is possible. In this case, destruction of a dielectric plug represented by paraffin is more effective. The features of this method are partially studied in the works $[13,14]$.

A waveguide can ensure several types of waves to propagate, but not all of them can easily be excited [20]. Especially if it concerns a source of electromagnetic waves pushed deep into the pipeline into a molten medium. It is necessary to study all possible options. In the presented scenario the propagation in a waveguide of $H_{11}$ waves, which has lowest critical frequency is considered [20].

In recent years, studies of application of electromagnetic fields to overcome oil and gas production have evolved in directions highlighted in the papers [21-28].

\section{Dielectric properties of asphaltene, resin and paraffin deposits}

Optimal methods for controlling ARPM depends on many factors, in particular, on methods of operating wells, thermobaric conditions in its wellbore, composition and properties of extracted products. It is possible to control the formation of a structure of asphaltene, resin and paraffin matter in the liquid produced by influencing these factors and the nature of relationships between paraffins, resins and asphaltenes. One of the techniques that allow affecting them is use of energy from highfrequency and microwave electromagnetic radiation.

As it seen from the data given in the previous section that interaction of ARPM with an electromagnetic field is determined by nature of dependence of its dielectric properties on frequency, temperature and pressure. These dependencies can only be determined experimentally.

ARPM is not a simple mixture of asphaltenes, resins and paraffins but a complex structured system with a pronounced core of asphaltenes and sorbtion-solvate layer of petroleum resins [1]. Asphaltene and resin matter are heterocyclic compounds of a complex hybrid state, which include nitrogen, sulfur, oxygen and metals $[39,40]$.

The table shows the properties of investigated samples of ARPM. As can be seen from the table, ARPM also contains mechanical impurities and sand in particular.

\section{Properties of ARPM samples}

\begin{tabular}{|l|c|c|}
\hline \multirow{2}{*}{\multicolumn{1}{|c|}{ Parameter }} & \multicolumn{2}{|c|}{ Object } \\
\cline { 2 - 3 } & $\begin{array}{c}\text { Vostochno- } \\
\text { Perevalnoye field, } \\
\text { Kogalymneftegaz, } \\
\text { reservoir A23 }\end{array}$ & $\begin{array}{c}\text { Yak 3-7, Well 540 } \\
\text { of Suzun-Vankor } \\
\text { field pipeline }\end{array}$ \\
\hline Asphaltenes, \% & 4 & 0.6 \\
\hline Resins, \% & 9 & 12 \\
\hline Paraffins, \% & 27 & 41 \\
\hline $\begin{array}{l}\text { Mechanical } \\
\text { contaminations, \% }\end{array}$ & 1.4 & 5 \\
\hline Oil residue, \% & 59 & 61 \\
\hline $\begin{array}{l}\text { Melting point of } \\
\text { ARPM, }{ }^{\circ} \mathrm{C}\end{array}$ & 53.6 & 63 \\
\hline $\begin{array}{l}\text { Melting point of } \\
\text { paraffin, }{ }^{\circ} \mathrm{C}\end{array}$ & 54 & 61 \\
\hline
\end{tabular}

An analysis shows that the dielectric method based on the features of the interaction of low- 
power HF EMF with inhomogeneous media is informative for determining the conditions for deposition of asphaltene, resin and paraffin substances in oil. For this purpose experimental studies of dielectric loss angle tangent $\operatorname{tg} \delta$ of oil with were conducted with addition of sand and paraffin, depending on frequency of electromagnetic oscillations in the range of $30-300 \mathrm{MHz}$ and temperature in the range of $25-80{ }^{\circ} \mathrm{C}$ by the kumeter method (Fig. 1).

Dependence of $\operatorname{tg} \delta$ of the media studied on frequency of electromagnetic oscillations obeys the regularities characteristic of polar liquids [27, 41]. Since the mass of measuring cell was maintained the same, $\operatorname{tg} \delta$ for oil with sand depends on sand amount - the more sand mass the less $\operatorname{tg} \delta$ of a mixture.

Approximating the data presented in Fig. $1 c$, it is possible to set the paraffin crystallization temperature from the value of the extremum tg $\delta$. For example, for oil with some paraffin added that is equal to $53 \pm 1{ }^{\circ} \mathrm{C}$, for Yak 3-7 formation $58 \pm 1{ }^{\circ} \mathrm{C}$, for layer Ach3 $-56 \pm 1{ }^{\circ} \mathrm{C}$. Moreover, $\operatorname{tg} \delta$ of media increases as the temperature increases. The regularity can be used to control the growth of paraffin crystals, and consequently, to control the formation of ARPM and prevent their formation.

\section{Monitoring of temperature change of asphaltene, resin and paraffin matter deposits in a well under influence of moving electromagnetic radiation}

This section discusses the numerical study of heating and melting of paraffin plugs in the equipment of oil pipelines by ultra high frequency electromagnetic radiation carried out.

Using equation (4) and assuming that solid deposits have completely clogged the pipeline the heat conduction equation is solved

$$
\begin{gathered}
\rho c_{T} \frac{\partial T}{\partial t}=\frac{1}{r} \frac{\partial}{\partial r}\left(\lambda r \frac{\partial T}{\partial r}\right)+ \\
\frac{\partial}{\partial z}\left(\lambda \frac{\partial T}{\partial z}\right)+Q(r, z, t),
\end{gathered}
$$

where $\rho, c_{T}, \lambda$ - density, heat capacity, thermal conductivity of the medium, heating and melting of which is produced.

The wave $\mathrm{H} 11$ has a cylindrical component of the electromagnetic field strength $E_{z}=0$ [14]. The rest field components are:

$$
\begin{gathered}
E_{r}=i \frac{\omega \mu_{0}}{\chi^{2} r} H_{0} J_{1}(\chi r) \sin \varphi \cdot e^{-i \alpha\left(z-z_{0}\right)} ; \\
E_{\varphi}=i \frac{\omega \mu_{0}}{\chi} H_{0} J_{1}^{\prime}(\chi r) \cos \varphi \cdot e^{-i \alpha\left(z-z_{0}\right)} ; \\
H_{r}=-i \frac{\alpha}{\chi} H_{0} J_{1}^{\prime}(\chi r) \cos \varphi \cdot e^{-i \alpha\left(z-z_{0}\right)} ; \\
H_{\varphi}=i \frac{\alpha}{\chi^{2} r} H_{0} J_{1}(\chi r) \sin \varphi \cdot e^{-i \alpha\left(z-z_{0}\right)} ; \\
H_{z}=H_{0} J_{1}(\chi r) \cos \varphi \cdot e^{-i \alpha\left(z-z_{0}\right)},
\end{gathered}
$$

where $i$ - imaginary unit; $\omega$ - circular frequency of the electromagnetic field; $\mu_{0}-$ magnetic constant (it is assumed that the medium in the waveguide on-magnetic dielectric); $\chi-$ transverse wave coefficient, $\chi=\frac{\mu_{n}}{R} ; \alpha$ - coefficient of attenuation of the power of electromagnetic waves along the waveguide, whose axis coincides with the axis of the cylindrical coordinate system $r, \varphi, z$, $\alpha=\alpha_{V}+\alpha_{S}=2 k_{z}^{\prime \prime} ; \alpha_{V}-$ damping factor caused by volume losses in a dielectric plug, $\alpha_{V}=\frac{\omega^{2}}{c^{2}} \frac{\varepsilon_{0}^{\prime \prime}}{k_{z}^{\prime}}$; $\alpha_{S}$ - damping factor caused by surface losses in the metal walls of a cylindrical waveguide, $\alpha_{S}=\frac{\omega \varepsilon_{0}^{\prime}}{c R k_{z}^{\prime}} \sqrt{\frac{\omega}{2 \pi \sigma}} ; c-$ speed of light; $\varepsilon_{0}^{\prime}, \varepsilon_{0}^{\prime \prime}-$ real and imaginary parts of the complex permittivity of paraffin, $\varepsilon_{0}=\varepsilon_{0}^{\prime}+i \varepsilon_{0}^{\prime \prime} ; k_{z}^{\prime}, k_{z}^{\prime \prime}$ - real and imaginary parts of the longitudinal wave number, $k_{z}=k_{z}^{\prime}+i k_{z}^{\prime \prime} ; \sigma-$ conductivity of the metal from which the pipe walls are made; $H_{0}$ - amplitude of magnetic field strength; $J_{1}-$ Bessel functions of the first order; ' - derivative sign; $z_{0}$ - coordinate of a mobile source of electromagnetic waves; at the beginning of an electromagnetic action the source is located at the point $z=0 ; \mu_{n}$ - the value of the $\mathrm{n}^{\text {th }}$ root of the Bessel function; $R$ - radius of the waveguide. For a wave of type $H_{11}-\mu_{n}=1.841$.

Some formulas in the present paper were derived based on formulas given [19].

As can be seen from the expressions (6)-(10), the electromagnetic field has two components of the electric field strength $E_{r}$ and $E_{\varphi}$. They determine distribution of thermal sources because 

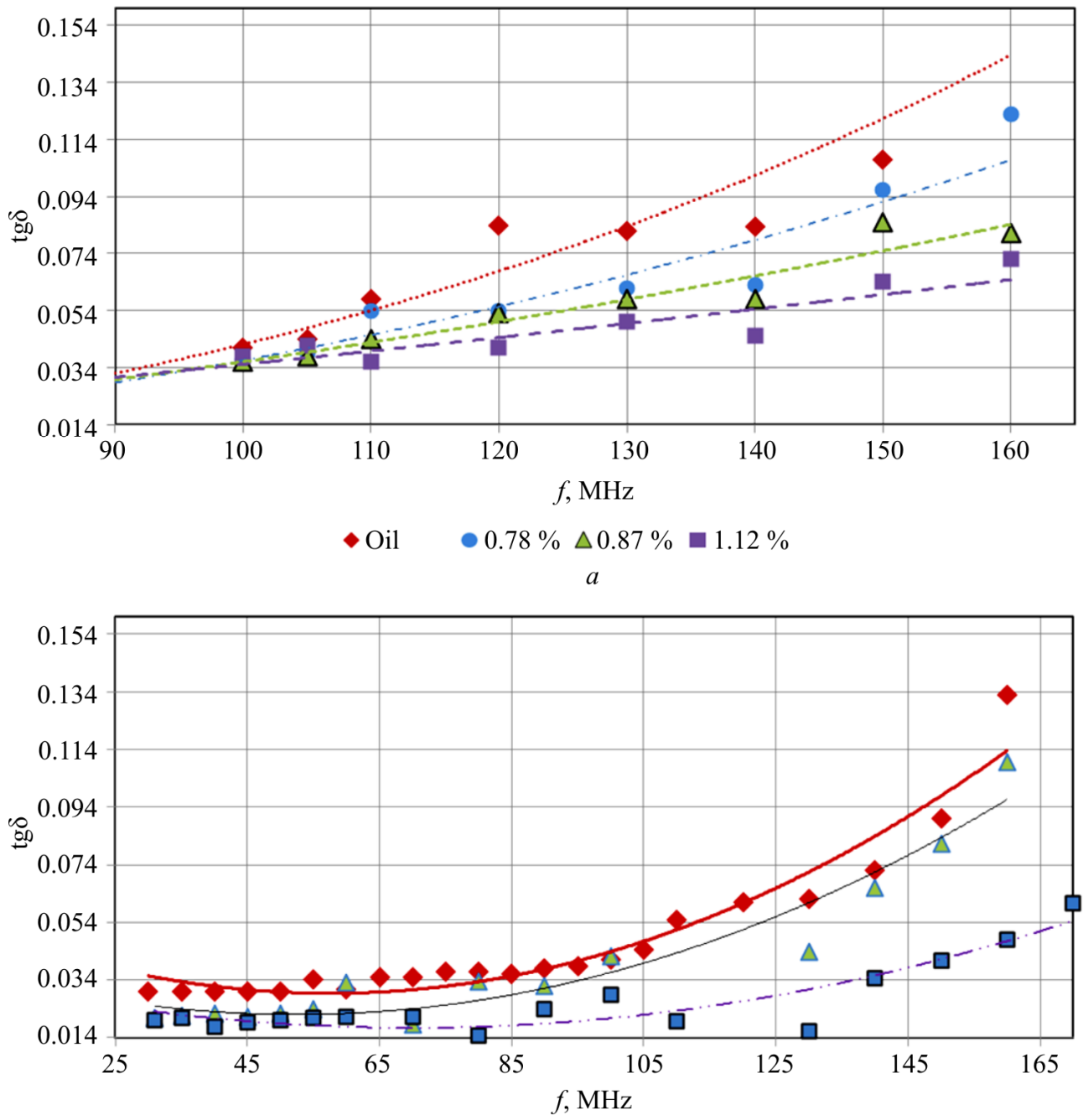

- Oil $\Delta$ Reservoir Ach3, Vostochno-Perevalnoye, Well 851 Yak 3-7, Well 540

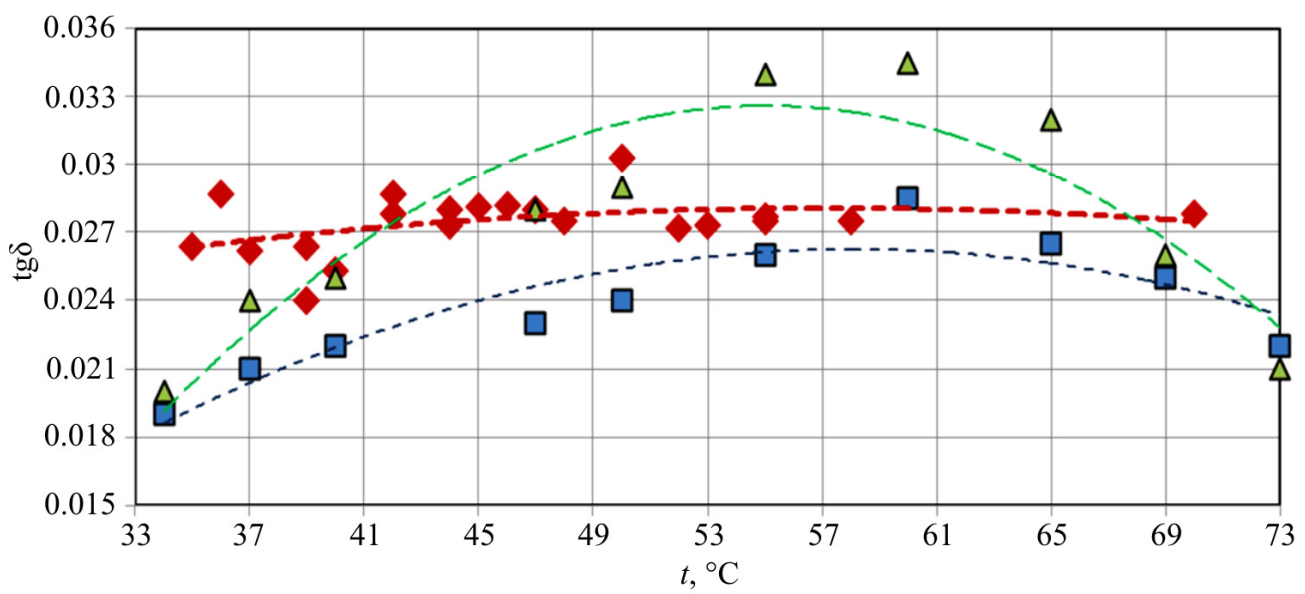

$\bullet$ Oil + paraffin $\quad \square$ Reservoir Yak 3-7, Well 540

$\triangle$ Reservoir Ach3, Vostochno-Perevalnoye, Well 851 $c$

Fig. 1. Dependence of the tangent of dielectric loss angle: $a$ - mixtures of oil with sand; $b$ - oil and ARPM samples from the frequency of electromagnetic oscillations; $c$ - oil with additional content of paraffin (ARPM) at frequency of $35 \mathrm{MHz}$ 
density of thermal sources is proportional to the sum of the squares of electric components of the electromagnetic field. The expression for density of thermal sources for a stationary source of work is given below

$$
\begin{gathered}
Q_{0}=\frac{\varepsilon_{0}^{\prime \prime}}{\pi \operatorname{Re}\left(k_{z} \varepsilon_{0}\right)} \frac{\mu_{n}^{2}}{R^{4}} P \times \\
\times\left[\frac{\left|k_{z}\right|^{2} R^{4}}{r^{2} \mu_{n}^{4}} J_{1}^{2}\left(\mu_{n} \frac{r}{R}\right) \sin ^{2} \varphi+\frac{\left|k_{z}\right|^{2} R^{2}}{\mu_{n}^{2}} \times\right. \\
\left.\times\left(J_{0}\left(\mu_{n} \frac{r}{R}\right)-\frac{R}{r \mu_{n}} J_{1}\left(\mu_{n} \frac{r}{R}\right)\right)^{2} \cos ^{2} \varphi\right],
\end{gathered}
$$

where $P$ - electromagnetic wave power.

There is a differentiation equation used in the expression (11) [15]

$$
J_{1}^{\prime}(\chi r)=J_{0}(\chi r)-\frac{J_{1}(\chi r)}{\chi r} .
$$

The problem is solved numerically by counting method without explicit phase separation. Density and thermal conductivity of oil are considered to be temperature-independent and heat capacity at the phase transition temperature TS has a $\delta$-shaped feature

$$
c_{T}=c_{0}+L \delta\left(T-T_{S}\right) \text {, }
$$

where $L$ - latent heat of phase transition; $\delta\left(T-T_{S}\right)$ - delta function.

Power density of volumetric heat release is written as

$$
Q=Q_{0} \Theta\left(z-z_{0}(t)\right) \exp \left(-\alpha\left(z-z_{0}(t)\right)\right) .
$$

The formula takes into account movement of the source of electromagnetic waves according to the law $z=z_{0}(t)$. The explicit form of $Q_{0}$ is given in expression (11). There is in the formula (13)

$$
\Theta\left(z-z_{0}\right)=\left\{\begin{array}{cc}
1, & z \geq z_{0} \\
0, & z<z_{0}
\end{array} .\right.
$$

The $\mathrm{P}$ value in expression (11) does not reflect the actual absorbed power of the electromagnetic energy. In order to determine it using the method of rectangles the volume integral was calculated

$$
Q_{\mathrm{gen}}=Q_{\mathrm{com}}=\int_{0}^{H} \int_{0}^{2 \pi} \int_{0}^{R} Q(r, z) r d r d \varphi d z,
$$

the coefficient which shows how much the actual absorbed power is different from the power set is calculated and then multiplied by the expression (11). In the integtal $H$ - length of the paraffin plug.

Dependence of an imaginary part of longitudinal wave number $k_{z}^{\prime \prime}$ frequency on electromagnetic field is given in Fig. 2. The critical frequency $H 11$ of a wave for the considered cylindrical waveguide with radius $R=0.0775 \mathrm{~m}-$ $f_{0} \approx 0.746 \cdot 10^{9} \mathrm{~Hz}$. The imaginary part of the longitudinal wave number has a minimum $k_{z}^{\prime \prime} \approx 0,2874 \mathrm{~m}^{-1}$ at the frequency $f \approx 1.06 \cdot 10^{9} \mathrm{~Hz}$. The Fig. 3 shows the distribution of density of heat sources $Q(r, \varphi, z=0)$ normalized to the power of source of electromagnetic waves in the cross section of the waveguide for the frequency $f=1.4 \cdot 10^{9} \mathrm{~Hz}$. For convinience of presentation cylindrical coordinates are transformed in Cartesian ones $x, y, z$. In this case, the circular waveguide is represented as a circle inscribed in a rectangle. As can be seen from the Fig. 3, distribution of thermal sources in cross section of the waveguide looks like an ellipse because it depends on an angle $\varphi$. Density of thermal sources strongly depends on the coordinate $r$ as well, and the higher the frequency of electromagnetic waves (i.e. distribution of thermal sources in a cross section of waveguide is very uneven) the stronger the depemdence. But this type of waves has an advantage in comparison with others - it has the lowest critical frequency, i.e. they can be most deeply heated along the cork. The maximum of thermal sources is obtained on the axis of a waveguide, but in general the configuration of the thermal sources does not depend on the frequency. Since it is most convenient to place the source of electromagnetic waves in the center of the tube that also gives an advantage. Density of thermal sources falls exponentially in the longitudinal direction.

It is yet possible to note the symmetry with respect to the right and left, upper and lower halves of the cross section of the waveguide in the Fig. 3. That allows considering processes only in a quarter of a circle and having an idea of what is going on in the whole circle. Thus, it is possible to save computer resources in the numerical computation of the problem and consider processes only in the $1^{\text {st }}$ quadrant. 


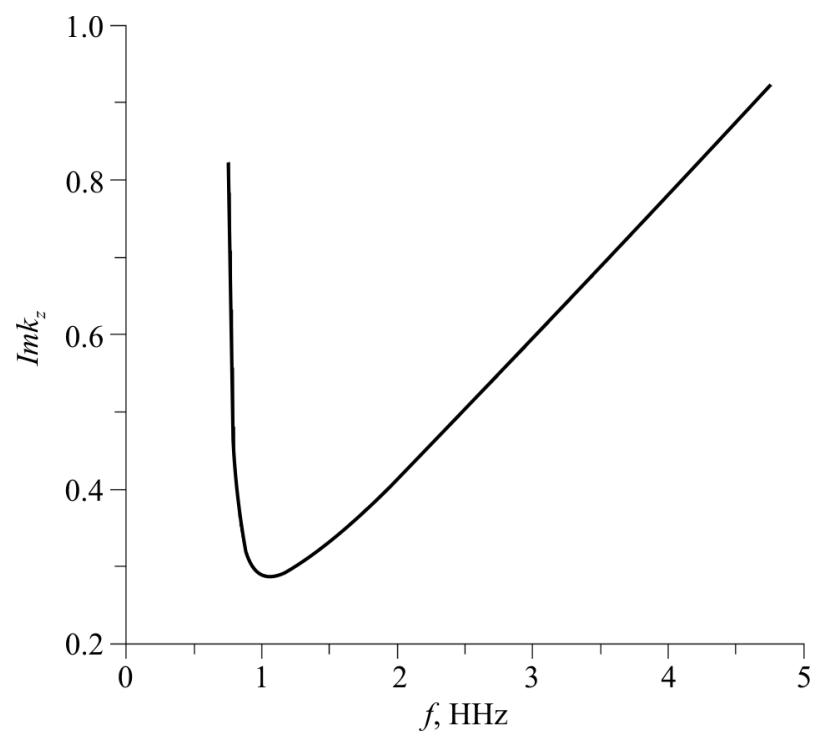

Fig. 2. Imaginary part of the longitudinal wave number as a function of frequency for a metal cylindrical waveguide filled with paraffin

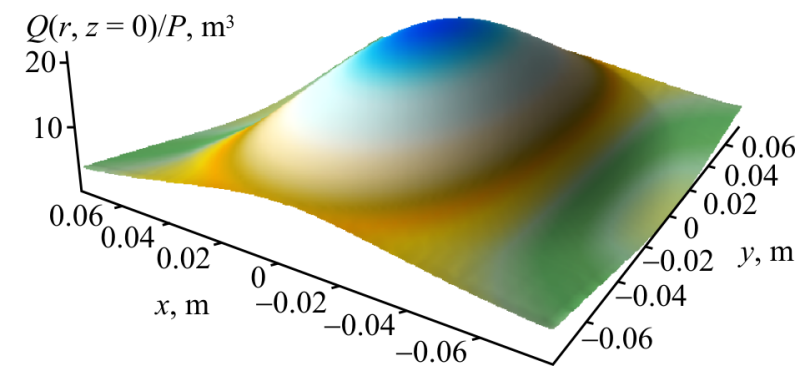

Fig. 3. Transverse distribution of density of thermal sources, normalized to powersource in a cylindrical waveguide

Boundary conditions were used to solve the equation (5). Convective heat transfer was determined according to Newton's law at the end of the plug, $z=0$

$$
\left.\lambda \frac{\partial T}{\partial z}\right|_{z=0}=\kappa_{1}\left(T-T_{0}\right),
$$

where $T_{0}$ - environment temperature and initial paraffin plugs; $\kappa_{1}$ - heat transfer coefficient.

There is no heat transfer at the remote end of the plug, $z=\mathrm{H}$ :

$$
\left.\lambda \frac{\partial T}{\partial z}\right|_{z=H}=0 .
$$

A boundary condition on the lateral surface of the cylinder $r=R$ was also written in terms of convective heat transfer, but with a different heat transfer coefficient $\kappa$ :

$$
-\left.\lambda \frac{\partial T}{\partial r}\right|_{r=R}=\kappa\left(T-T_{0}\right),
$$

where $\kappa-$ coefficient of heat exchange with external environment, $\kappa=\mathrm{Nu} \cdot \lambda / R ; \mathrm{Nu}-$ Nusselt number.

There is no heat transfer at the point $r=0$ :

$$
-\left.\lambda \frac{\partial T}{\partial r}\right|_{r=0}=0 .
$$

Solving the problem in the $1^{\text {st }}$ quadrant only it is possible to consider following conditions

$$
-\left.\lambda \frac{\partial T}{\partial \varphi}\right|_{\varphi=0}=0 ;-\left.\lambda \frac{\partial T}{\partial \varphi}\right|_{\varphi=\frac{\pi}{2}}=0 .
$$

The velocity of a source of electromagnetic waves $\mathrm{v}$ along the coordinate $\mathrm{z}$ was set constant and chosen so that there were no zones with unmelted paraffin behind the source (in calculations the value of $\mathrm{v}$ equal to $1.5 \mathrm{~m} / \mathrm{h}$ was used)..

During the calculation studies the following parameters of high paraffin oil were used: $\rho=$ $=950 \mathrm{~kg} / \mathrm{m}^{3} ; c_{0}=3 \mathrm{~kJ} /(\mathrm{kg} \cdot \mathrm{K}) ; \lambda=0.125 \mathrm{~W} /(\mathrm{m} \cdot \mathrm{K})$; $L=3 \mathrm{MJ} / \mathrm{kg} ; \kappa=1.613 \mathrm{~W} /\left(\mathrm{m}^{2} \cdot \mathrm{K}\right) ; \mathrm{Nu}=1$ (pipe in dry ground $) ; \kappa_{1}=0,2 \mathrm{~W} /\left(\mathrm{m}^{2} \cdot \mathrm{K}\right) ; T_{0}=20{ }^{\circ} \mathrm{C}$; $T_{S}=50^{\circ} \mathrm{C} ; H=5 \mathrm{~m} ; P=6.5 \mathrm{~kW} ; f=1.4 \cdot 10^{9} \mathrm{~Hz}$; $\varepsilon_{0}^{\prime}=2.3 ; \operatorname{tg} \delta=\varepsilon_{0}^{\prime \prime} / \varepsilon_{0}^{\prime}=0.012 ; \sigma=3.4 \cdot 10^{6} \mathrm{Ohm}^{-1} \cdot \mathrm{m}^{-1}$. The challenge was overcame by an implicit method of alternating directions with a uniform rectangular grid. The delta function in the expression for thermal conductivity was approximated by a step with a half-width equal to $0.4^{\circ} \mathrm{C}$.

Results of numerical simulation of heating and melting process of the paraffin plug "EM Krot" for different time are shown in Fig.4.

The Fig. $4 a$ shows temperature distributions in a cross-section of pipeline in Cartesian coordinates at different distances from the beginning of the plug; $4 b-$ in a longitudinal section of pipeline in cylindrical coordinates at various angles $\varphi$ before the start of the "EM Krot" movement; $4 c$ - after the beginning of movement of "EM Krot" at the speed of $v=1.5 \mathrm{~m} / \mathrm{h}$.

The "EM Krot" began to move 135 minutes after the start of the heating process. For convenience of imaging the Fig. $4 b$ all values along the coordinate $r$ were multiplied by 100 . 

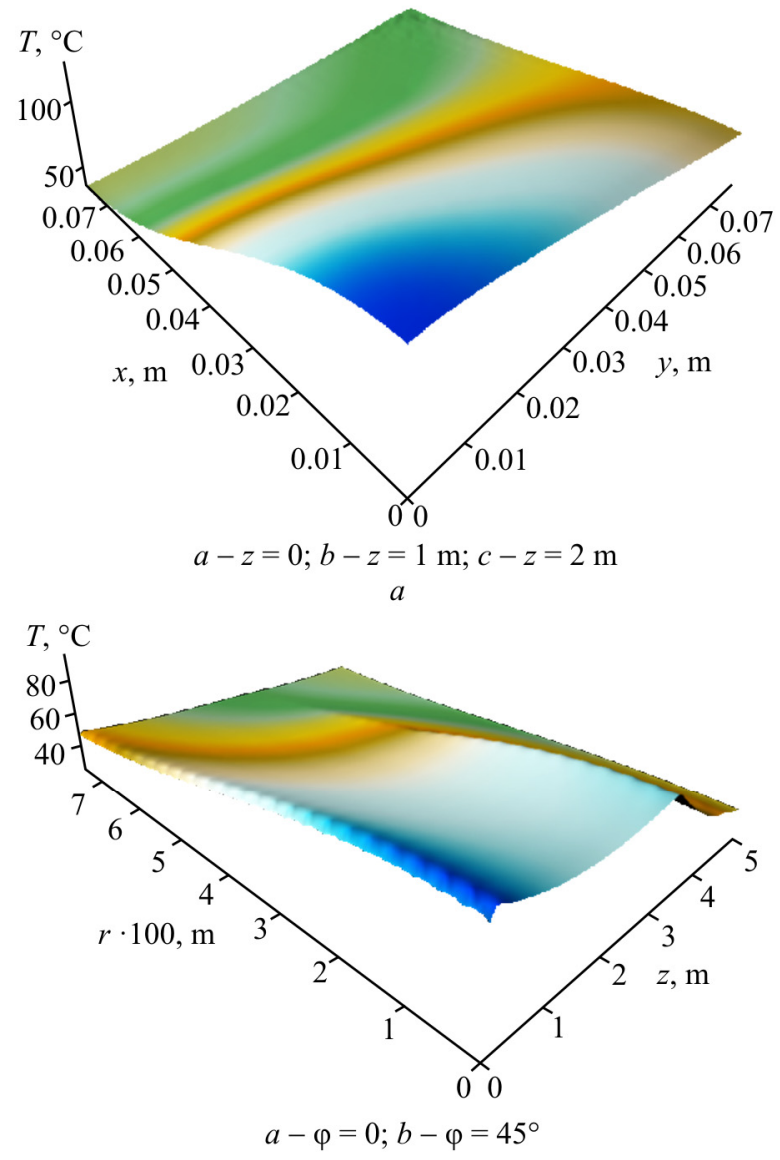

As can be seen from the figures, the process of medium heating depends strongly on density distribution of thermal sources. Location of the initial penetration of the cork is completely determined by the maximum density of thermal sources. Temperature distribution over the time

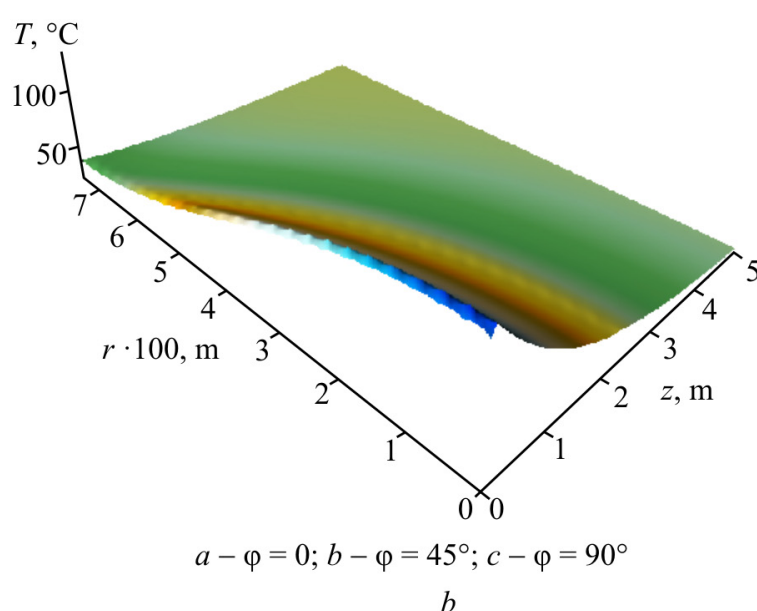

Fig. 4. Temperature distribution in a cylindrical waveguide filled with paraffin: $a$ - transverse, $t=135 \mathrm{~min} ; b$ - longitudinal, $t=135 \mathrm{~min} ; c-$ longitudinal, $t=4.5 \mathrm{~h}$

becomes more uniform in the transverse direction due to thermal conductivity of a medium and in longitudinal direction due to motion of the "EM Krot". In order to melt a plug along the entire cross-section of the pipeline "EM Krot" movement has to start a long time after the start of heating.

\section{References}

1. Galkin S.V. Accounting methods of geological risks on the stage of oil fields exploration. Perm Journal of Petroleum and Mining Engineering, 2012, no.4, pp.23-32.

2. Persiiantsev M.N. Dobycha nefti v oslozhnennykh usloviiakh [Extraction of oil under complicated conditions]. Moscow, Nedra-Biznestsentr, 2000, 653 p.

3. Krasnov V.A. Tekhnologiia i oborudovanie dlia dobychi nefti iz skvazhin oslozhnennykh asfaltosmoloparafinovymi otlozheniiami [Technology and equipment for production of oil from wells that are complicated by wax deposits], available at: http://runeft.ru/library/articles/ 46/5222/ (accessed 15 May 2018).

4. Metody borby $\mathrm{s}$ otlozheniiami parafina $\mathrm{v}$ fontannykh skvazhinakh [Methods of controlling paraffin deposits in fountain wells], available at: http://neftandgaz.ru/?p=425 (accessed 15 May 2018).
5. Tronov V.P. Mekhanizm obrazovaniia smoloparafinovykh otlozhenii [Mechanism of formation of resin and paraffin deposits]. Moscow, Nedra, 1970, 192 p.

6. Turbakov M.S., Riabokon E.P. Cleaning efficiency upgrade of oil pipeline from wax deposition. Perm Journal of Petroleum and Mining Engineering, 2015, no.17, pp.54-62. DOI:10.15593/2224-9923/2015.17.6

7. Ustkachkintcev E.N., Melekhin S.V. Determination of the efficiency of wax deposition prevention methods. Perm Journal of Petroleum and Mining Engineering, 2016, vol.15, no.18, pp.61-70. DOI: 10.15593/2224-9923/2016.18.7

8. Zlobin A.A. Study of mechanism of oil magnetic activation in order to protect production wells from wax deposition. Perm Journal of Petroleum and Mining Engineering, 2017, vol.16, no.1, pp.49-63. DOI: $10.15593 / 2224-9923 / 2017.1 .6$ 
9. Iusupova T.N., Barskaia E.E., Ganeeva Iu.M., Amerkhanov I.I., Khisamov R.S. Issledovanie vozmozhnosti osazhdeniia asfaltosmoloparafinovykh veshchestv v stvole skvazhiny i prizaboinoi zone plasta pri snizhenii [Identification of wax deposits in the bottom-hole formation zone and wellbore in reducing of the pressure]. Oil industry, 2016, no.1, pp.39-41.

10. Saiakhov F.L., Fatykhov M.A., Imashev N.Sh. Sposob elektrodeparafinizatsii skvazhin [Method of electrodeparafinization of wells]. Otkrytiia. Izobreteniia, 1989, no.35, 4 p. A.s. 1314756 SSSR.

11. Akhmetov A.T., Diachuk A.I., Kislitsyn A.A. et al. Sposob likvidatsii ledianykh gazogidratnykh i parafinovykh probok $\mathrm{v}$ vykidnykh liniiakh skvazhin $\mathrm{i}$ truboprovodakh [The method of eliminating ice, gas hydrate and paraffin plugs in the discharge lines of wells and pipelines]. Otkrytiia. Izobreteniia, 1992, no.3, pp.120. A.s. 1707190 SSSR.

12. Kislitsyn A.A. Chislennoe modelirovanie vysokochastotnogo elektromagnitnogo progreva dielektricheskoi probki, zapolniaiushchei trubu [Numerical simulation of high-frequency electromagnetic heating of a dielectric stopper filling the pipe]. PMTF, 1996, vol.37, no.3, pp.75-82.

13. Balakirev V.A., Sotnikov G.V., Tkach Iu.V., Iatsenko T.Iu. SVCh-metod ustraneniia parafinovykh probok v neftianykh skvazhinakh [Microwave method for eliminating paraffin plugs in oil wells]. SVCh-tekhnika $i$ sputnikovye telekommunikatsionnye tekhnologii. Trudy 9 Krymskoi vystavki i konferentsii. Sevastopol, 1999, pp.422-424.

14. Balakirev V.A., Sotnikov G.V., Tkach Iu.V., Iatsenko T.Iu. Razrushenie asfaltoparafinistykh otlozhenii $\mathrm{v}$ neftianykh truboprovodakh dvizhushchimsia istochnikom vysokochastotnogo elektromagnitnogo izlucheniia [Destruction of asphalto-paraffinic deposits in oil pipelines by a moving source of high-frequency electromagnetic radiation]. Zhurnal tekhnicheskoi fiziki, 2001, vol.41, iss.9, pp.1-8.

15. Balakirev V.A., Sotnikov G.V., Tkach Iu.V., Iatsenko Ti.U. Ustranenie parafinovykh probok $\mathrm{V}$ oborudovanii neftianykh skvazhin i neftianykh truboprovodakh vysokochastotnym elektromagnitnym izlucheniem [Removal of paraffin plugs in the equipment of oil wells and oil pipelines by high-frequency electromagnetic radiation]. Elektromagnitnye iavleniia, 2001 vol.2, no.3(7), pp.123-145.

16. Fatykhov M.A. Osobennosti nagreva i plavleniia parafina $\mathrm{V}$ koaksialnoi sisteme pod vozdeistviem vysokochastotnogo elektromagnitnogo izlucheniia [Characteristics of heating and melting of paraffin in a coaxial system under the influence of high-frequency electromagnetic radiation]. Teplofizika vysokikh temperatur, 2002, vol.40, no.5. pp.802-809.

17. Fatykhov M.A., Fatykhov L.M., Microwave electromagnetic method of melting the paraffin plug in an apen coaxial system. Journal of Engineering Physics and Thermophysics, 2015, vol.88, is.3, pp.724-729. DOI: 10.1007/s10891-015-1242-2

18. Fatykhov M.A. Research of the depth of heating of highly viscous dielectric liquid under high-frequency electromagnetic field using the method of dimensional theory. Surface Engineering and Applied Electrochemistry, 2016, vol.52, iss.1, pp.79-84. DOI: 10.3103/S1068375516010051

19. Balakirev V.A., Sotnikov G.V., Tkach Iu.V., Iatsenko Ti.U. Razrushenie asfaltoparafinistykh otlozhenii v neftianykh truboprovodakh dvizhushchimsia istochnikom vysokochastotnogo elektromagnitnogo izlucheniia [Destruction of asphalto-paraffinic deposits in oil pipelines by a moving source of high-frequency electromagnetic radiation]. Zhurnal tekhnicheskoi fiziki, 2001, vol.41, iss.9, pp.1-8.

20. Didenko A.N., Zverev B.V. SvCH-energetika [Microwave energy]. Moscow, Nauka, 2000, 264 p.

21. Kovaleva L.A., Zinnatullin R.R., Mullayanov A.I., Shrubkovskii I.I. Experimental studies of Heating rheologically complex fluids with electromagnetic field. High Temperature, 2016, vol.54, no.4, pp.612-614. DOI: 10.1134/S0018151X1604012X

22. Davletbaev A., Kovaleva L., Babadagli T. Combining solvent injection electromagnetic heating and hydraulic fracturing for multistage heavy oil recovery. Journal of Electromagnetic Waves and Applications, 2016, vol.30, no.2, pp.207-224. DOI: 10.1080/09205071.2015.1102093

23. Kovaleva L., Musin A. Numerical modeling of heavy hydrocarbon liquid heating. Brazilian Journal of Chemical Engineering, 2016, vol.33, no.1, pp.169-175. DOI: 10.1590/0104-6632.20160331s20140101

24. Davletbaev A.Y., Kovaleva L.A., Nasyrov N.M., Babadagli T. Multi-stage hydravlic fracturing and radio-frecuency electromagnetic radiation for heavy-oil production. Journal of Unconventional Oil and Gas Resources, 2015, vol.12, pp.15-22. DOI: 10.1016/j.juogr.2015.08.002

25. Bera A., Babadagli T. Effect of native and injected nano-particles on the efficiency of heavy oil recovery by radio frequency electromagnetic heating. Journal of Petroleum Science and Engineering, 2017, vol.153, pp.244-256. DOI: 10.1016/j.petrol.2017.03.051

26. Bera A., Babadagli T. Status of electromagnetic heating for enhanced heavy oil/bitumen recovery and future procpects: a review. Applied Energy, 2015, vol.151, pp.206-226. DOI: 10.1016/j.apenergy.2015.04.031

27. Kovaleva L.A., Zinnatullin R.R. The determination of temperature - frequence and dielectric characteristics of oils. High Temperature, 2006, vol.44, no.6, pp.954-956. DOI: 10.1007/s10740-006-0115-y

28. Kashif M., Yahya N., Zaid H.M., Shafie A., Jasamai M., Nasir N., Akhter M.N. Oil recovery by using 
electromagnetic waves. Journal of Applied Sciences, 2011, 11, pp.1366-1370. DOI: 10.3923/jas.2011.1366.1370

29. Chakma A., Jha K.N. Heavy oil recovery from thin pay zones by electromagnetic heating. Proceedings of the 67th Annual Technical Conference and Exhibition. Washington, DC, 1992, pp.10-11. DOI: 10.2118/24817-MS

30. Chhetri A.B., Islam M.R. A critical review of electromagnetic heating for enhanced oil recovery. Petroleum Sci. Technol, 2008, 26, pp.1619-1631. DOI: 10.1080/10916460701287607

31. Gunal O.G., Islam M.R. Alteration of ahphaltic crude rheology with electromagnetic and ultrasonic irradiation. Journal of Petroleum Science and Engineering, 2000, 26, pp.263-272. DOI: 10.1016/S0920-4105(00)00040-1

32. Hamouda A.A., Karoussi O. Effect of temperature, wettability and relative permeability on oil recovery from oil-wet chalk. Energies, 2008, 1, pp.19-34. DOI: 10.3390/en1010019

33. Jarvis J.B., Inguva R. Mathematical model for in situ oil shale retorting by electromagnetic radiation. Fuel, 1988, vol.67, iss.7, pp.916-926. DOI: 10.1016/0016-2361(88)90090-7

34. Rangel-German E.R., Schembre J., Sandberg C., Kovscek A.R. Electrical-heating-assisted recovery for heavy oil. J. Petroleum Sci. Eng, 2004, 45, pp.213-231. DOI: $10.1016 /$ j.petrol.2004.06.005

35. Sahni A., Kumar M., Knapp R.B. Electromagnetic heating methods for heavy oil reservoirs. Proceedings of the SPE/AAPG Western Regional Meeting. Long Beach, 2000, pp.10-11. DOI: 10.2118/62550-MS

36. Soliman M.Y. Approximate solutions for flow of oil heated using microwaves. J. Petroleum Sci. Eng, 1997, vol.18, iss.1-2, pp.93-100. DOI: 10.1016/S0920-4105(97)00007-7

37. Sresty G.C., Dev H., Snow R.H., Bridges J.E. Recovery of bitumen from tar sand deposits with the radio frequency process. SPE Reservoir Eng, 1986, 1, pp.85-94. DOI: $10.2118 / 10229-P A$

38. Vermeulen F., McGee B. In situ electromagnetic heating for hydrocarbon recovery and environmental remediation. J. Can. Petroleum Technol, 2000, 39, pp.24-28. DOI: 10.2118/00-08-DAS

39. Sharifullin A.V., Baibekova L.R., Suleimanov A.T. Osobennosti sostava i stroeniia neftianykh otlozhenii [Features of composition and structure of oil deposits]. Tekhnologiia nefti i gaza, 2006, no.6, pp.19-24.

40. Sharifullin A.V., Baibekova L.R. Sostav i struktura asfaltosmoloparafinovykh otlozhenii tatarstana [Composition and structure of asphaltosmolo-paraffin deposits of Tatarstan]. Tekhnologiia nefti $i$ gaza, 2006, no.6, pp.34-41.

41. Chistiakov S.I., Denisova N.F., Saiakhov F.L. Eksperimentalnoe issledovanie zavisimosti dielektricheskikh svoistv nefti i ee fraktsii ot chastoty [Experimental study of dependence of dielectric properties of oil and its fractions on frequency]. Izvestiia vysshikh uchebnykh zavedenii. Neft i gaz, 1972, no.5, pp.53-56.

\section{Библиографический список}

1. Галкин С.В. Методология учета геологических рисков на этапе поисков и разведки нефтяных месторождений // Вестник Пермского национального исследовательского университета. Геология. Нефтегазовое и горное дело. - 2012. № 4. - С. 23-32.

2. Персиянцев М.Н. Добыча нефти в осложненных условиях. - М.: Недра-Бизнесцентр, 2000. - 653 с.

3. Краснов В.А. Технология и оборудование для добычи нефти из скважин, осложненных асфальтосмолопарафиновыми отложениями [Электронный pecypc]. - URL: http://runeft.ru/ library/articles/46/5222/ (дата обращения: 15.05.2018).

4. Методы борьбы с отложениями парафина в фонтанных скважинах [Электронный ресурс]. URL: http://neftandgaz.ru/?p=425 (дата обращения 15.05.2018).

5. Тронов В.П. Механизм образования смолопарафиновых отложений. - М.: Недра, 1970. - 192 с.

6. Турбаков М.С., Рябоконь Е.П. Совершенствование эффективности очистки нефтепроводов от отложений парафинов // Вестник Пермского национального исследовательского политехнического университета.
Геология. Нефтегазовое и горное дело. - 2015. - № 17. C. 54-62. DOI:10.15593/2224-9923/2015.17.6

7. Устькачкинцев Е.Н., Мелехин С.В. Определение эффективности методов предупреждения асфальтосмолопарафиновых отложений // Вестник Пермского национального исследовательского политехнического университета. Геология. Нефтегазовое и горное дело. - 2016. - Т. 15, № 18. - С. 61-70. DOI:10.15593/2224-9923/2016.18.7

8. Злобин А.А. Изучение механизма магнитной активации нефти для защиты добывающих скважин от асфальтосмолопарафиновых отложений // Вестник Пермского национального исследовательского политехнического университета. Геология. Нефтегазовое и горное дело. - 2017. - Т. 16, № 1. - С. 49-63. DOI:10.15593/2224-9923/2017.1.6

9. Исследование возможности осаждения асфальтосмолопарафиновых веществ в стволе скважины и призабойной зоне пласта при снижении забойного давления / Т.Н. Юсупова, Е.Е. Барская, Ю.М. Ганеева, И.И. Амерханов, Р.С. Хисамов // Нефтяное хозяйство. - 2016. - № 1 . C. 39-41. 
10. Саяхов Ф.Л., Фатыхов М.А., Имашев Н.Ш. Способ электродепарафинизации скважин // Открытия. Изобретения. - 1989. - № 35. - 4 с. А.с. 1314756 CCCP.

11. Способ ликвидации ледяных, газогидратных и парафиновых пробок в выкидных линиях скважин и трубопроводах / А.Т. Ахметов, А.И. Дьячук, А.А. Кислицын [и др.] // Открытия. Изобретения. 1992. - № 3. - C. 120. A.c. 1707190 CCСР.

12. Кислицын А.А. Численное моделирование высокочастотного электромагнитного прогрева диэлектрической пробки, заполняющей трубу // ПМТФ. 1996. - Т. 37, № 3. - С. 75-82.

13. СВЧ-метод устранения парафиновых пробок в нефтяных скважинах / В.А. Балакирев, Г.В. Сотников, Ю.В. Ткач, Т.Ю. Яценко // СВЧ-техника и спутниковые телекоммуникационные технологии: тр. 9-й Крымской и выставки и конференции. Севастополь, 1999. - С. 422-424.

14. Разрушение асфальтопарафинистых отложений в нефтяных трубопроводах движущимся источником высокочастотного электромагнитного излучения / В.А. Балакирев, Г.В. Сотников, Ю.В. Ткач, Т.Ю. Яценко // Журнал технической физики. - 2001. - Т. 41, вып. 9. C. $1-8$.

15. Устранение парафиновых пробок в оборудовании нефтяных скважин и нефтяных трубопроводах высокочастотным электромагнитным излучением / В.А. Балакирев, Г.В. Сотников, Ю.В. Ткач, Т.Ю. Яценко // Электромагнитные явления. - 2001. Т. 2, № 3 (7). - C. 123-145.

16. Фатыхов М.А. Особенности нагрева и плавления парафина в коаксиальной системе под воздействием высокочастотного электромагнитного излучения // Теплофизика высоких температур. 2002. - T. 40, № 5. - C. 802-809.

17. Fatykhov M.A., Fatykhov L.M. Microwave electromagnetic method of melting the paraffin plug in an apen coaxial system // Journal of Engineering Physics and Thermophysics. - 2015. - Vol. 88, iss. 3. - P. 724-729. DOI: $10.1007 / \mathrm{s} 10891-015-1242-2$

18. Fatykhov M.A. Research of the depth of heating of highly viscous dielectric liquid under high-frequency electromagnetic field using the method of dimensional theory // Surface Engineering and Applied Electrochemistry. - 2016. Vol. 52, iss 1. - P. 79-84. DOI: 10.3103/S1068375516010051

19. Разрушение асфальтопарафинистых отложений в нефтяных трубопроводах движущимся источником высокочастотного электромагнитного излучения / В.А. Балакирев, Г.В. Сотников, Ю.В. Ткач, Т.Ю. Яценко // Журнал технической физики. - 2001. Т. 41, вып. 9. - С. 1-8.

20. Диденко А.Н., Зверев Б.В. СВЧ-энергетика. М.: Наука, 2000. - 264 с.
21. Experimental studies of Heating rheologically complex fluids with electromagnetic field / L.A. Kovaleva, R.R. Zinnatullin, A.I. Mullayanov, I.I. Shrubkovskii // High Temperature. - 2016. - Vol. 54, № 4. - P. 612-614. DOI: 10.1134/S0018151X1604012X

22. Davletbaev A., Kovaleva L., Babadagli T. Combining solvent injection electromagnetic heating and hydraulic fracturing for multistage heavy oil recovery // Journal of Electromagnetic Waves and Applications. - 2016. - Vol. 30, № 2. - P. 207-224. DOI: 10.1080/09205071.2015.1102093

23. Kovaleva L., Musin A. Numerical modeling of heavy hydrocarbon liquid heating // Brazilian Journal of Chemical Engineering. - 2016. - Vol. 33, № 1. - P. 169175. DOI: 10.1590/0104-6632.20160331s20140101

24. Multi-stage hydravlic fracturing and radiofrecuency electromagnetic radiation for heavy-oil production / A.Y. Davletbaev, L.A. Kovaleva, N.M. Nasyrov, T. Babadagli // Journal of Unconventional Oil and Gas Resources. - 2015. - Vol. 12. - P. 15-22. DOI: 10.1016/j.juogr.2015.08.002

25. Bera A., Babadagli T. Effect of native and injected nano-particles on the efficiency of heavy oil recovery by radio frequency electromagnetic heating // Journal of Petroleum Science and Engineering. - 2017. - Vol. 153. P. 244-256. DOI: 10.1016/j.petrol.2017.03.051

26. Bera A., Babadagli T. Status of electromagnetic heating for enhanced heavy oil/bitumen recovery and future procpects: a review // Applied Energy. - 2015. - Vol. 151. P. 206-226. DOI: 10.1016/j.apenergy.2015.04.031

27. Kovaleva L.A., Zinnatullin R.R. The determination of temperature - frequence and dielectric characteristics of oils // High Temperature. - 2006. - Vol. 44, № 6. - P. 954956. DOI: $10.1007 / \mathrm{s} 10740-006-0115-\mathrm{y}$

28. Oil recovery by using electromagnetic waves / M. Kashif, N. Yahya, H.M. Zaid A. Shafie, M. Jasamai, N. Nasir, M.N. Akhter // Journal of Applied Sciences. 2011. - 11. - P. 1366-1370. DOI: 10.3923/jas.2011.1366.1370

29. Chakma A., Jha K.N. Heavy oil recovery from thin pay zones by electromagnetic heating // Proceedings of the 67th Annual Technical Conference and Exhibition. Washington, DC, 1992. - P. 10-11. DOI: 10.2118/24817-MS

30. Chhetri A.B., Islam M.R. A critical review of electromagnetic heating for enhanced oil recovery // Petroleum Sci. Technol. - 2008. - 26. - P. 1619-1631. DOI: $10.1080 / 10916460701287607$

31. Gunal O.G., Islam M.R. Alteration of ahphaltic crude rheology with electromagnetic and ultrasonic irradiation // Journal of Petroleum Science and Engineering. - 2000. - 26. - P. 263-272. DOI: 10.1016/S0920-4105(00)00040-1

32. Hamouda A.A., Karoussi O. Effect of temperature, wettability and relative permeability on oil recovery from oil-wet chalk // Energies. - 2008. - 1. - P. 19-34. DOI: 10.3390/en1010019 
33. Jarvis J.B., Inguva R. Mathematical model for in situ oil shale retorting by electromagnetic radiation // Fuel. - 1988. - Vol. 67, iss. 7. - P. 916-926. DOI: $10.1016 / 0016-2361(88) 90090-7$

34. Electrical-heating-assisted recovery for heavy oil / E.R. Rangel-German, J. Schembre, C. Sandberg, A.R. Kovscek // J. Petroleum Sci. Eng. - 2004. - 45. P. 213-231. DOI: 10.1016/j.petrol.2004.06.005

35. Sahni A., Kumar M., Knapp R.B. Electromagnetic heating methods for heavy oil reservoirs // Proceedings of the SPE/AAPG Western Regional Meeting. Long Beach, CA, 2000. - P. 10-11. DOI: 10.2118/62550-MS

36. Soliman M.Y. Approximate solutions for flow of oil heated using microwaves // J. Petroleum Sci. Eng. 1997. - Vol. 18, iss. 1-2. - P. 93-100. DOI: $10.1016 / \mathrm{S} 0920-4105(97) 00007-7$

37. Recovery of bitumen from tar sand deposits with the radio frequency process / G.C. Sresty, H. Dev,
R.H. Snow, J.E. Bridges // SPE Reservoir Eng. - 1986. Vol. 1. - P. 85-94. DOI: 10.2118/10229-PA

38. Vermeulen F., McGee B. In situ electromagnetic heating for hydrocarbon recovery and environmental remediation // J. Can. Petroleum Technol. - 2000. - 39. P. 24-28. DOI: 10.2118/00-08-DAS

39. Шарифуллин А.В., Байбекова Л.Р., Сулейманов А.Т. Особенности состава и строения нефтяных отложений // Технология нефти и газа. - 2006. - № 6. C. 19-24.

40. Шарифуллин А.В., Байбекова Л.Р. Состав и структура асфальтосмолопарафиновых отложений Татарстана // Технология нефти и газа. - 2006. - № 6. C. $34-41$.

41. Чистяков С.И., Денисова Н.Ф., Саяхов Ф.Л. Экспериментальное исследование зависимости диэлектрических свойств нефти и ее фракций от частоты // Известия высших учебных заведений. Нефть и газ. - 1972. - № 5. - С. 53-56.

Please cite this article in English as:

Fatykhov L.M. Cleaning the well from wax deposition by high-frequency and ultra high-frequency electromagnetic exposure. Perm Journal of Petroleum and Mining Engineering, 2018, vol.17, no.2, pp.152-165. DOI: 10.15593/2224-9923/2018.2.5

Просьба ссылаться на эту статью в русскоязычных источниках следующим образом:

Фатыхов Л.М. Технология очистки скважин от асфальтеносмолопарафиновых отложений путем воздействия высокочастотного и сверхвысокочастотного электромагнитного излучения // Вестник Пермского национального исследовательского политехнического университета. Геология. Нефтегазовое и горное дело. - 2018. - Т.17, №2. C.152-165. DOI: $10.15593 / 2224-9923 / 2018.2 .5$ 